\title{
Productive and Reproductive Performances of Hilly and Jungle Fowl
}

\author{
M. M. Rahman ${ }^{1}$, S. Faruque ${ }^{2}$, M. S. Islam²*, M. M. Islam ${ }^{3}$ and A. Mahmud ${ }^{4}$ \\ ${ }^{1}$ Biotechnology Division; ${ }^{2}$ Poultry Production Research Division; ${ }^{3}$ System Research Division, \\ Bangladesh Livestock Research Institute (BLRI), Savar, Dhaka; ${ }^{4}$ Regional Station, Bangladesh \\ Livestock Research Institute, Naikhongchari, Bandarbhan. Bangladesh \\ *Corresponding author and Email: siraj_blri@yahoo.com
}

Received: 15 April $2013 \quad$ Accepted: 06 December 2013

\begin{abstract}
A total of 43 (38 females and 5 males) adult native hilly chicken and 63 day-old chicks (44 hilly and 19 jungle fowl) were studied to understand their productive and reproductive performances under intensive management. The hen day egg production of hilly chicken during 11 months production period was $22.10 \%$ and average egg weight was $42.6 \mathrm{~g}$. The adult body weights of female and male birds were $1701 \mathrm{~g}$ and $2690 \mathrm{~g}$, respectively. The average daily feed consumption per bird was $101 \mathrm{~g}$ during laying period. Hatchability of hilly chicken eggs was $91.35 \%$. The day old chick weight of hilly chicken and jungle fowl was $29.4 \mathrm{~g}$ and $19.6 \mathrm{~g}$, respectively $(P \leq 0.01)$. The body weight of hilly and jungle fowl were $503.8 \mathrm{~g}$ and $344.8 \mathrm{~g}$, respectively, $(P \leq 0.05)$. There was no significant difference between hilly chicken and jungle fowl for feed consumption. Feed conversion ratios (FCR) were 2.80 and 4.4 for hilly chicken and jungle fowl, respectively $(P \leq 0.05)$. Mortality of adult birds during laying period was $16.4 \%$ and there was no chick mortality up to 8 weeks of age. Hilly chicken has shown potentiality to be used as meat type chicken. They require to reproduction freely under captivity to have a large number of breeding stocks for undertaking conservation and improvement programme.
\end{abstract}

Keywords: Improvement, conservation, hilly chicken, jungle fowl

\section{Introduction}

Hilly chickens are native birds of hilly area of Bangladesh and reared for local consumption. Eggs and meat of hilly chickens have unique taste, delicacy and popularity among consumers. Local non-descript coloured chicken is a vital source of tasty meat and eggs and is more acceptable to rural people (Barua and Howlider, 1990). The local people often try to have the indigenous cockerel for its softness and special taste (Ahmed and Ali, 2007). However, the growth pattern and egg production characteristics of hilly chicken are not well documented. The heavier body size of the hilly chickens indicates that it can be used meat type chicken in Bangladesh. Faruque et al. (2010) observed significant variations in native chickens of Common Deshi, Hilly and Naked Neck chicken, under intensive management. Khatun et el. (2005) reported $1429 \mathrm{~g}$ body weight of hilly chicken at 38 weeks of age. Bhuiyan et al. (2009) reported that deshi chickens are genetically diluted in about $60 \%$ cases depending on phenotypic character. Indiscriminate random breeding among native chickens and unplanned crossing with exotic breed have been eroding the original characteristics of native chicken. So, the local genetic resources have been going under threat gradually. Conservation of genetic resources as insurance against future needs has become a topic of mounting concern (Crawford, 
1984). The local germplasm of hilly chicken must be collected and conserved in adequate numbers for future use. Selection for pure breeding is also necessary for their improvement. However, before going to conserve and improve the local genotypes, it is crucial to know their productive and reproductive characteristics under intensive management conditions. The present study was therefore, undertaken with a view to examine their productive performances; and examine their reproductive performances under full captivity.

\section{Materials and Methods}

Locally collected 38 females and 5 males of hilly chicken were identified by wing band. The birds were put in the open sided poultry house of BLRI regional station at Naikhongchari, Bandarban Hill district. Sufficient number of hanging feeders and round drinkers were placed in the poultry house. Commercially available broiler starter and grower feeds were offered adlibitum to the birds. Rice husk was used as litter material. Birds were dewormed at a regular interval. A proper vaccination schedule was followed against Ranikhet and Fowl Pox diseases.

Sufficient floor space was allowed for free movement of birds within the house. Nest was set to encourage egg laying. Hatching eggs from hilly chicken and jungle fowl were collected separately and sent to BLRI head quarters at Savar, Dhaka for hatching. The newly hatched chicks were identified and placed in separate pens in a brooder house with adlibitum feed and water. The chicks were grown on littered floor with rice husk up to 8 weeks of age.

Data on egg production, egg weight, fertility, hatchability, feed consumption, body weight and mortality were recorded regularly. Data were analyzed using computer program of SPSS (version 14). The differences among means were tested using Least Significant Difference (LSD) method.

\section{Results and Discussion}

The performances of hilly chicken are shown in Table 1 . Hen day egg production of hilly chicken during 11 months study period was $22.10 \%$. It was substantially lower than that of Faruque and Salahuddin (2009) who reported $34.66 \%$ but close to previous findings of Rahman et al. (2010) who reported $23.03 \%$ from $2001 \mathrm{~g}$ above body weight group. The average egg weight of hilly chicken was $42.6 \mathrm{~g}$, which was higher than that reported by Faruque et al. (2010) who reported egg weight of $40 \mathrm{~g}$. This finding also close to the findings of Rahman et al. (2010) who reported 42.2-42.7 $\mathrm{g}$ from 1401-2000 $\mathrm{g}$ body weight groups of hilly chicken.

The average daily feed intake of hilly chicken during laying period was $101 \mathrm{~g}$ and it was close to the findings of Rahman et al. (2010). The mortality of hilly chicken during 11 months rearing period was $16.4 \%$ which seems to be very high under intensive management. The age variation of the experimental hilly birds might be one of the reasons of higher mortality (Rahman et al., 2010). The average body weights of productive female and male hilly chicken were $1701.6 \mathrm{~g}$ and $2690 \mathrm{~g}$, respectively which were close to that of one of the hilly chicken group reported by Rahman et al. (2010). Fertility of hatching eggs of hilly chicken was $96.33 \%$ which was close to the results of Faruque et al. (2013) who reported $97.57 \%$ fertility of hilly bird. Hatchability of eggs of hilly chicken was $91.35 \%$ which was higher than the findings of Rahman et al. (2010) who reported $85.41 \%$ by natural hatching.

The performances of hilly and jungle fowl chicks are presented in Table 2. The body weight of day old chicks were $29.4 \mathrm{~g}$ and $19.6 \mathrm{~g}$, respectively for hilly chicken and jungle fowl and difference was significant $(P \leq 0.01)$. The day old weight of hilly chicken was $29.4 \mathrm{~g}$, which is close to the findings of Rahman et al. (2010) who reported $28.7 \mathrm{~g}$ and Faruque et al. (2012) who reported 28 g. 
Table 1. Performances of hilly chicken reared for 11 months at Naikhongchari Regional Station of BLRI

\begin{tabular}{ll}
\hline Parameters & Value(Mean \pm SD) \\
\hline Hand day egg production(\%) & $22.10 \pm 0.35$ \\
Egg weight $(\mathrm{g})$ & $42.6 \pm 0.80$ \\
Feed consumption( g/bird/day) & $101 \pm 2.79$ \\
Mortality (\%) & $16.40 \pm 0.41$ \\
Body weight $(\mathrm{g})$ & male $2690 \pm 279.5$ \\
& female $1701.6 \pm 374.2$ \\
Fertility (\%) & $96.33 \pm 8.96$ \\
Hatchability $(\%)$ & $91.35 \pm 3.21$ \\
\hline
\end{tabular}

Table 2. Performances of hilly and jungle fowl chicks up to 8 weeks of age

\begin{tabular}{llcc}
\hline Parameters & \multicolumn{2}{c}{ Value(Mean \pm SD) } & Level of \\
& Sig. \\
\cline { 2 - 3 } & Hilly chicken & Jungle fowl & $* *$ \\
Day old chicks weight (g/bird) & $29.4 \pm 1.20$ & $19.6 \pm 0.80$ & $*$ \\
Live weight at 8 weeks (g/bird) & $503.8 \pm 77.80$ & $344.8 \pm 63.70$ & NS \\
Feed consumption(g/bird) & $1411.0 \pm 75.21$ & $1521 \pm 37.12$ & $*$ \\
Feed Conversion Ratio & $2.8 \pm 0.093$ & $4.41 \pm 0.26$ & - \\
Mortality $(\%)$ & - & - & \\
\hline
\end{tabular}

**Significantly different at $(P \leq 0.01)$, *significantly different at $(P \leq 0.05)$ and NS=Non-significant

The day old chicks weight of jungle fowl was $19.6 \mathrm{~g}$ which was lower than that of nondescript Deshi of $27.7 \mathrm{~g}$ (Faruque et al., 2011). The body weight of hilly and jungle fowl were $503.8 \mathrm{~g}$ and $344.8 \mathrm{~g}$, respectively $(P \leq 0.05)$. There was no significant difference between hilly chicken and jungle fowl for feed consumption. The FCR were 2.80 and 4.41 in hilly chicken and jungle fowl, respectively $(P \leq 0.05)$. The results of present study were better than the findings of Faruque et al. (2012) who reported 3.16 at 4 weeks of age. There was no chick mortality up to 8 weeks of age (Table 2).

\section{Conclusions}

It may be concluded that hilly chicken has potentiality to be used as meat type chicken. They are required to reproduce freely under captivity to have a large number of breeding stocks for undertaking conservation and improvement programme.

\section{References}

Ahmed, S.T. and Ali, M.A. 2007. Performance of Synthetic, Desi, Synthetic $\times$ Desi and Synthetic $\times$ Star cross brown chicken at marketing. In: Proceedings of the $5^{\text {th }}$ International Poultry Show and Seminar, Organized by World's Poultry Science Association-Bangladesh Branch, 01-03 March, 2007, 18-25 pp.

Barua, A. and Howlider, M. A. R. 1990. Prospect of native chicken in Bangladesh. Poultry Advisor, 23: 57-61.

Bhuiyan, A. K. F. H., Biswas, S. R. and Biswas, J. C. 2009. Genetic dilution of indigenous chicken in selected villages of 
Bangladesh. In: Proceedings of the Sixth International Poultry Show and Seminar, Organized by World's Poultry Science Association-Bangladesh Branch, 05-07 March, 2009, 147-162 pp.

Crawford, R. D. 1984. Assessment and conservation of animal genetic resources in Canada. Canadian Journal of Animal Science, 64: 235-251.

Faruque, S., Afroz, M. A. and Islam, M. S. 2010. Evaluation of response to selection in chicken. International Journal of Biological Research, 1(4):01- 05.

Faruque, S., M. S. Islam, M. A. Afroz and M. M. Rahman. 2013. Evaluation of the performance of native chicken and estimation of heritability for body weight. Journal of Bangladesh Academy of Sciences, 37(1): 93-101.

Faruque, S., Rahman, M. M. and Islam, M. N. 2010. Conservation and development of native chicken genetic resources in Bangladesh. Paper presented in annual research review workshop \& technology show, 22-23 June, 2010, BLRI, Savar, Dhaka.

Faruque, S. and Salah Uddin, M. 2009. Study on molecular genetic diversity of native chicken in Bangladesh. In :Proceedings of the annual research review workshop. 17-18 June, 2009 BLRI, Savar, Dhaka, Bangladesh.
Faruque, S., Bhuiyan, A. K. F. H., Islam, M. N. and Rahman, M. M. 2011. Breeding for the improvement indigenous chickens of Bangladesh. Paper presented in annual research review workshop \& technology show, Paper presented in annual research review workshop \& technology show, BLRI, Savar, Dhaka. 24-25 June, 2011, 78-91 pp.

Faruque, S., Bhuiyan, A. K. F. H., Bhuiyan, M. S. A., Islam, M. N. and Rahman, M. M. 2012. Conservation and improvement of indigenous chickens. Paper presented in annual research review workshop \& technology show, Paper presented in annual research review workshop \& technology show, BLRI, Savar, Dhaka. 24-25 June, 2012, 68-69 pp.

Khatun, R., Islam, M. S., Faruque, S. Azmal, S. A. and Uddin, M. S. 2005. Study on the productive and reproductive performances of three native genotypes of chicken under intensive management. Journal of the Bangladesh Agricultural University, 3: 99-104.

Rahman, M. M., Islam, M. M. and Mohanta, U. K. 2010. Improvement of Hilly chicken in Bangladesh. Paper presented in annual research review workshop \& technology show, BLRI, Savar, Dhaka, Bangladesh, 22-23 June 2010. 